\title{
The Near-Death Experience: A Study of Spiritual Transformation
}

\author{
Cassandra Musgrave \\ Destination Light, Lake Oswego, OR
}

ABSTRACT. Fifty-one near-death experiencers (NDErs) were surveyed in person and through the mail to discover if and how their lives were changed as a result of their NDEs. Results showed major changes in participants' lives, especially in the areas of religious belief and practice, lifestyle, career, and relationships.

The near-death experience (NDE), innately transformative by nature, enhances not only the experiencer, but also others who may be touched in some way by the NDEr. Accounts of NDEs most often reflect an indescribably glorious afterlife filled with great peace, balance, harmony, and magnificent love vastly unlike our often stressful earthly lives. The NDE strongly suggests that death is not a final destination, but part of a wondrous journey to yet another level of the soul's spiritual development. Many experiencers reveal that in the "light" of the other side, surrounded by profoundly loving caretakers, their real spiritual nature is reawakened and they are truly "home."

Through my private practice, I have been involved in others' personal processes, sometimes assisting in the assimilation of their NDEs, as well as the near-death or death experiences of their loved

Cassandra Musgrave is a transpersonal counselor, psychic, lecturer, minister, and hospice worker, through her business, Destination Light. This paper was adapted from a research report originally written for a class at George Fox College in Newberg, OR. The author wishes to extend her personal thanks to Kimberly Clark Sharp, M.S.W., Tricia Richie, Lynn Johnson, Ph.D., Thelma Huffman, Elane Durham, and Bruce Greyson, M.D., for their support, and to the members of the Seattle, WA, Portland, OR, and Salt Lake City, UT, chapters of the Friends of IANDS who participated in this survey. Reprint requests should be addressed to Ms. Musgrave at Destination Light, 267 Cervantes Circle, Lake Oswego, OR 97035. 
ones. Those who had prior knowledge of the positive spiritual aspects of the near-death process were greatly comforted in their times of need when a loved one died or nearly died. For the experiencer, direct knowledge of a heavenly existence kindles an incontestable inner knowing that most often eliminates any future fear of death. For the nonexperiencer, such knowledge can also decrease a fear both of death and of the mysterious unknown after death. Thus, in our world of increasing disturbance, near-death studies can offer benefit, inspiration, and knowledge to a humanity hungry for inner peace and truth. Such information can provide courage and spiritual direction for one's daily life and when a soul makes its transition to yet another realm of existence.

Twenty years have passed since Raymond Moody's first groundbreaking book on the NDE opened the door for the scientific, psychological, and spiritual study of this previously little-known subject (Moody, 1975). In the past twenty years considerable research has been conducted on NDEs, which has suggested that NDErs become more spiritual in a personal way and less religious in a formalized way. NDErs also become more open-minded regarding spirituality and religion. In addition, they become more open-minded in general, have reduced or lost fear of death, feel emotionally stronger and less fearful of life, are more service-oriented, are more appreciative of life, are more compassionate and understanding towards others, have developed astute intuitive abilities, and are much more aware of being guided by God or a higher power than before their NDE (Ring, 1984).

My own personal thirst for "the Divine" and my endless fascination with the spiritual aspects of the near-death experience led me to develop this particular NDE survey and subsequent research. The purpose of this study was to investigate the purported life-changing impact of the near-death experience (NDE) on individuals. The intent was to discover if and how NDErs' lives have been changed as a result of their coming close to death. The set of questions used in this study was developed to focus previous researchers' themes, specifically to study whether the lives of NDErs have been changed as a result of their near-death experiences, and if so, how. The hypothesis to be tested was that each NDEr's life has been changed in significant ways, as a result of his or her near-death experience, particularly in the area of spirituality or religious belief and practice. 


\section{Methods}

\section{Subjects}

The International Association for Near-Death Studies (IANDS) sponsors local chapters (Friends of IANDS) to serve as a contact point for near-death survivors, their families, professionals, and others interested in NDEs. Friends of IANDS is a community-based network of support and discussion groups around the world that share information through the auspices of the organization. It offers support, sharing, discussion, and education at monthly meetings.

The participants in this study were recruited from members of the Seattle, Portland, and Salt Lake City chapters of the Friends of IANDS. The Seattle Chapter of Friends of IANDS (Seattle IANDS) was started in 1982, the Portland Chapter (Portland IANDS) in 1993, and the Salt Lake City Chapter (Utah IANDS) in 1992. Attendance averages approximately 100 individuals (range $=60-300$ ), about onethird of whom have had NDEs, at the Seattle meetings; approximately 16 (range = 10-30), one-fourth of whom have had NDEs, at the Portland meetings; and approximately 80 (range $=10-100$ ), onefourth of whom have had NDEs, at the Salt Lake City meetings.

The majority of the participants in this study attended the May 7, 1994, meeting in Seattle, where surveys were distributed; other members of the chapter who did not attend offered to complete surveys by mail. Survey participants must have had an actual NDE.

Fifty-one surveys were given to participants, and all 51 were returned in usable form.

\section{Materials}

The questionnaire used was compiled specifically for this study. After preliminary research, a list of questions was compiled that would best serve the survey purpose and ultimate hypothesis. Twice, the questions were revised after receiving suggestions from pilot subjects.

Thirty-one multiple choice questions were used. Six dealt with the actual NDE and served to establish that an actual near-death experience occurred. These questions, derived from previous near-death research and including particular experiential elements considered essential to a classic NDE, were used to measure the individual's NDE. 
Twenty questions were designed to examine beliefs, feelings, and behavior before and after the NDE, to explore changes in the spiritual, emotional, professional, personal, and practical subjects' lives.

Two questions established the subject's willingness to share the experience, based on others' reactions. Two other questions established subjects' age at the time of the NDE and at the time of the survey.

\section{Procedures}

The proposed project and survey requirements were discussed with the presidents of the Seattle, Portland, and Salt Lake City groups, and permission was granted to offer surveys to qualified members at monthly meetings and through the mail.

In May 1994, surveys with cover letters were given to the 51 individuals who agreed to participate, some at the Seattle meeting and others, from all three chapters, through the mail.

\section{Results}

Friends of IANDS participants returned 51 surveys for a return rate of 100 percent. The results of this survey are presented in the order in which questions were asked on the questionnaire.

1. Have you ever had a near-death experience?

All 51 subjects reported they had had at least one NDE. A total of $64 \mathrm{NDEs}$ were reported, for a mean of 1.3 experiences per respondent.

\section{What caused your NDE?}

All 51 subjects responded with at least one event that caused the NDE. A total of 64 precipitating events were reported, for a mean of 1.3 events per person. The most common causal event reported was accident, listed for 23 NDEs (36 percent); illness was reported for $16 \mathrm{NDEs}$ (25 percent), surgery for $12 \mathrm{NDEs}$ (19 percent), drug overdose for $3 \mathrm{NDEs}$ (5 percent), and dental treatment for 2 NDEs (3 percent). Heart attack, being choked, electrocution, war wounds, seizures, hanging from a cliff, childbirth, and emotional shock were each reported for $1 \mathrm{NDE}$ ( 2 percent). 
3. During the NDE did you perceive yourself to be dying or on a path toward death?

Twenty-seven repondents (53 percent) answered "yes" to this question; 23 (45 percent) answered "no," and 4 respondents ( 8 percent), including 3 who had answered "yes" or "no," said they were not sure.

4. In retrospect, how close did you come to actual death?

Nineteen respondents (37 percent) reported that they were "most likely dead"; 29 respondents ( 57 percent) reported that they had been "obviously close to death"; 5 (10 percent) reported they were "not sure if death would have occurred"; and 3 ( 6 percent) reported they had been in "no real danger of dying." (Total responses exceeded 100 percent because 5 respondents gave more than one answer.)

5. During the NDE did you experience any of the following?

Specific phenomena reported are listed in Table 1, along with number and percent of subjects reporting them.

6. If you saw spirit beings, who were they?

Thirty-nine subjects (76 percent) reported seeing some spirit being or beings. A total of 111 responses were reported, for a mean of 2.2 responses per subject. Seventeen respondents (33 percent) described these beings as "familiar to $m e^{\text {", and }} 11$ ( 22 percent) described them as "not familiar to me."

Sixteen respondents ( 31 percent) described them as light beings, teachers, or guides; 14 (28 percent) described them as deceased relatives or friends; 12 (24 percent) described them as angels or angeliclike beings; 12 (24 percent) described the being as Jesus Christ; 5 (10 percent) described them as just "some being"; 3 (6 percent) described it as "God as energetic presence"; and 2 (4 percent) described a "lady in white." "Many souls," historical or Biblical figures, a grandmother, one's spiritual self, a greeter, "eternity as entity," and a "singular light/sound presence" were each described by 1 respondent (2 percent).

7. Do you recall coming back to life?

Forty-one respondents ( 80 percent) answered "yes" to this question, and 12 (24 percent) answered "no"; 2 subjects answered both "yes" and "no." 


\begin{tabular}{|c|c|}
\hline Phenomenon & Respondents \\
\hline $\begin{array}{l}\text { peace, painlessness, pleasantness } \\
\text { seeing, enveloped by, or entering light } \\
\text { being separated from the body } \\
\text { entering a dark region or tunnel } \\
\text { hearing a voice or voices } \\
\text { sense of existing as "mind" only } \\
\text { seeing or greeting spirits } \\
\text { choosing to return to life } \\
\text { life review } \\
\text { being told not to die, or to return to life } \\
\text { subjective sense of being dead } \\
\text { had no choice but to return to life } \\
\text { seeing or reaching a border of life } \\
\text { choosing to return to life } \\
\text { being asked if ready to die } \\
\text { hearing noises like wind or buzzing } \\
\text { hearing news of own death } \\
\text { hearing music } \\
\text { feelings of wonder or awe } \\
\text { seeing colorful beings } \\
\text { being asked if he or she wanted to stay } \\
\text { being told not to be afraid }\end{array}$ & $\begin{array}{r}46 \text { (90 percent) } \\
39 \text { (77 percent) } \\
37 \text { (73 percent) } \\
36 \text { (71 percent) } \\
35 \text { (69 percent) } \\
32 \text { (63 percent) } \\
29 \text { (57 percent) } \\
23 \text { (45 percent) } \\
20 \text { (39 percent) } \\
20 \text { (39 percent) } \\
18 \text { (35 percent) } \\
16 \text { ( } 31 \text { percent) } \\
16 \text { (31 percent) } \\
12 \text { (24 percent) } \\
11 \text { (22 percent) } \\
11 \text { (22 percent) } \\
7 \text { (14 percent) } \\
3 \text { ( } 6 \text { percent) } \\
2 \text { ( } 4 \text { percent) } \\
2 \text { ( } 4 \text { percent) } \\
1 \text { ( } 2 \text { percent) } \\
1 \text { ( } 2 \text { percent) }\end{array}$ \\
\hline
\end{tabular}

8. At the time, were you angry at coming back to life?

13 respondents (26 percent) answered "yes"; 5 (10 percent) answered "somewhat"; and 34 (67 percent) answered "no." One respondent gave two answers and another gave no response.

9. What was your religious denomination before your NDE?

Twenty-three respondents (45 percent) described themselves before the NDE as Protestant, 11 (22 percent) as Mormon, 6 (12 percent) as Catholic, 4 (8 percent) as Episcopal, 3 (6 percent) as Baptist, 2 (4 percent) as Assembly of God, 2 (4 percent) as Lutheran, 2 (4 percent) as Unity; 1 (2 percent) as Anglican, 1 (2 percent) as Methodist, 
1 (2 percent) as Greek Orthodox, 1 (2 percent) as New Thought Christian; and 1 (2 percent) as Jewish.

In addition, 15 respondents ( 29 percent) described themselves before the NDE as "spiritually oriented, not church involved"; 6 (12 percent) described themselves as agnostic; 4 ( 8 percent) as having no religious denomination; and 1 (2 percent) as atheist.

10. What is your religious denomination since your NDE

Eight respondents (16 percent) described themselves now as Mormon; 6 (12 percent) as Unity; 5 (10 percent) as Protestant; 2 (4 percent) as Catholic; 2 (4 percent) as New Thought Christian; 1 (2 percent) as Assembly of God; 1 (2 percent) as Baptist; 1 (2 percent) as Lutheran; 1 (2 percent) as Pentecostal; 1 (2 percent) as Presbyterian; 1 (2 percent) as Church of the Master; and 1 (2 percent) as Eckankar.

In addition, 29 respondents (57 percent) described themselves now as "spiritually oriented, not church involved"; 2 (4 percent) as having no religious denomination; 1 (2 percent) as agnostic; and 1 ( 2 percent) as atheist.

11. How spiritual (personal) and/or religious (church) were you before your NDE?

Seven respondents (14 percent) answered that they had been "very" spiritual or religious before the NDE; 15 (29 percent) answered "quite" spiritual or religious; 13 (26 percent) answered "fairly" spiritual or religious; 10 (20 percent) answered "not too" spiritual or religious; 5 (10 percent) answered "not at all"; and 1 respondent did not answer.

12. How spiritual (personal) or religious (church) are you since your NDE?

Thirty-four respondents (67 percent) answered that they are now "very" spiritual or religious; 10 (20 percent) answered "quite" spiritual or religious; 2 (4 percent) answered "fairly" spiritual or religious; 3 (6 percent) answered "not too" spiritual or religious; and 2 (4 percent) answered "not at all."

13. Before your NDE how strong was your belief in God?

Twelve respondents (24 percent) described their belief in God before the NDE as "absolute"; 12 (24 percent) described it as "strong"; 15 (29 percent) described it as "fairly strong"; 2 (4 percent) described 
it as "not too strong"; 1 (2 percent) described it as "nonexistent"; and 9 respondents (18 percent) answered that they were unsure.

\section{Since your NDE, how strong is your belief in God?}

Forty-two respondents (82 percent) described their belief in God now as "absolute"; 5 (10 percent) described it as "strong"; 1 (2 percent) described it as "fairly strong"; 1 (2 percent) described it as "not too strong"; and 2 (4 percent) described it as "nonexistent."

15. Before your NDE, did you believe there was one path to God?

Fourteen respondents (28 percent) answered "yes"; 14 (28 percent) answered "no"; and 23 (45 percent) answered that they were unsure.

16. Since your NDE, do you believe there is one path to God?

Thirteen respondents (26 percent) answered "yes"; 33 (65 percent) answered "no"; and 5 (10 percent) answered that they were unsure.

17. Before your NDE, did you believe in an afterlife?

Eleven respondents (22 percent) answered "definitely"; 7 (14 percent) answered "strongly"; 15 (29 percent) answered "probably"; 3 (6 percent) answered "not at all"; and 15 (29 percent) answered that they were unsure.

18. Since your NDE, do you believe in an afterlife?

Forty-seven respondents (92 percent) answered "definitely"; 3 (6 percent) answered "strongly"; and 1 (2 percent) answered "not at all."

19. Since your NDE, what are your feelings regarding a fear of death?

Thirty-five respondents (69 percent) answered that they had lost all fear of death; 10 (20 percent) answered that they had decreased fear of death; 8 (16 percent) answered that they had never been afraid of death; and 2 (4 percent) reported no change in feelings. None reported increased fear of death. (Total responses exceed 100 percent because 4 respondents gave more than one response.)

20. Before your NDE, what were your conceptions of death?

All 51 respondents answered, and gave a total of 93 responses, for a mean of 1.8 answers per subject. Thirteen respondents ( 25 percent) answered that they conceived of death as a transition or new beginning; 12 (24 percent) answered that their conception of death in- 
cluded heaven and hell; 7 (14 percent) had a conception of death that relates to reincarnation; 4 (8 percent) answered that their conception of death included heaven only; 6 (12 percent) answered that they had a conception of death as finality; and 43 (84 percent) answered that they were not sure.

\section{Since your NDE, what are your conceptions of death?}

Fifty respondents (98 percent) answered, and gave a total of 146 answers, for a mean of 2.9 responses per subject. Of those 50 respondents, 47 (92 percent) answered they they conceived of death as a transition or new beginning; 19 (37 percent) answered that they had a conception of death that relates to reincarnation; 3 (6 percent) answered that their conception of death included heaven and hell; 45 (90 percent) answered that their conception of death included heaven only; 1 ( 2 percent) answered that he conceived of death as annihilation or finality; 3 (6 percent) responded "not sure"; and 1 (2 percent) gave no response.

22. Since your NDE, have you changed in the following ways?

Specific changes are listed in Table 2, along with numbers and percents of respondents reporting them.

\section{Are you angry now at having returned to life?}

Two respondents (4 percent) answered "yes"; 9 (18 percent) answered "somewhat"; and 40 (78 percent) answered "no."

24-A. Since your NDE, have you experienced changes in career?

Twenty-six respondents (51 percent) reported a positive change; 5 (10 percent) reported a negative change; 10 (20 percent) reported a neutral change; and 12 (24 percent) gave no response.

24-B. Since your NDE, have you experienced changes in lifestyle?

Thirty-seven respondents (73 percent) reported a positive change; 3 (6 percent) reported a negative change; 7 (14 percent) reported a neutral change; and 6 (12 percent) gave no response.

24-C. Since your NDE, have you experienced changes in relationships?

Forty respondents (78 percent) reported a positive change; 9 (18 percent) reported a negative change; 3 (6 percent) reported a neutral change; and 3 (6 percent) gave no response. 


\section{Table 2}

Specific Changes Reported by NDErs $(\mathbf{N}=61)$

\begin{tabular}{lc}
\hline \multicolumn{1}{c}{ Change } & Respondents \\
\hline more helpful toward others & 42 (82 percent) \\
more compassionate or understanding & 42 (82 percent) \\
more open-minded in general & 42 (82 percent) \\
more spiritually or religiously open & 41 (80 percent) \\
more intuitive & $40(78$ percent) \\
more aware of guidance by higher power & $38(75$ percent) \\
more appreciative of life & $37(73$ percent) \\
emotionally stronger & $35(69$ percent) \\
more purposeful & $33(65$ percent) \\
less fearful of life & $26(51$ percent $)$ \\
more depressed & $4(8$ percent) \\
a "born again" Christian & $3(6$ percent $)$ \\
more fearful & $1(2$ percent) \\
more fearful of life & $1(2$ percent) \\
\hline
\end{tabular}

24-D. Since your NDE, have you experienced changes in spirituality?

Forty-five respondents ( 88 percent) reported a positive change; none reported a negative change; 3 (6 percent) reported a neutral change; and 3 (6 percent) gave no response.

\section{Has your NDE changed you?}

Fifty subjects (98 percent) responded, and gave a total of 251 answers, for a mean of 4.9 answers per subject.

Forty-eight respondents (94 percent) answered that the NDE changed them spiritually; 42 (82 percent) answered that it changed them mentally; 31 (61 percent) answered that it changed them physically; 23 (45 percent) answered that it changed them professionally; 16 (31 percent) answered that it changed them financially; and 4 (8 percent) answered that it changed them emotionally.

In addition, 44 respondents ( 86 percent) answered that the NDE changed them for the better; while 3 (6 percent) answered that it changed them for the worse. 
26. In general, since the NDE how much has your life changed?

Thirty-nine respondents (77 percent) answered "dramatically"; 6 (12 percent) answered "somewhat"; 3 (6 percent) answered "not at all"; and 3 (6 percent) gave no response.

27. If you feel you have found your purpose in life, do you attribute it to having had an NDE?

Twenty-six respondents (51 percent) answered "yes"; 11 (22 percent) answered "somewhat"; 3 (6 percent) answered "no"; 8 (16 percent) answered that they had not found their purpose; and 3 (6 percent) gave no response.

28. When sharing your NDE, how have others reacted?

Thirty-five subjects (69 percent) answered that others had been open and receptive; 16 (32 percent) answered that others had been disbelieving and skeptical.

29. In general, how do you feel about sharing your NDE?

Twelve respondents (24 percent) answered that they were open and willing to share their NDE; 39 (76 percent) answered that they were fearful of ridicule or negativity.

30. Exactly how old were you at the time of your NDE?

All 51 respondents provided answers for a total of 64 different NDEs. The mean age at the time of the first NDE was 29.2 years.

31. What is your present age?

The mean age of the 51 respondents was 51.9 years.

\section{Discussion}

This survey confirmed the study hypothesis. Survey results suggest that one's sense of personal spirituality and willingness or interest in subscribing to outer religious influences, such as church, were radically altered after the NDE, indicating major change in the area of personal spirituality and formalized religious practice. The majority of experiencers, regardless of religious affiliation, became more spiritually oriented and less church-oriented after the NDE. For these experiencers, it appears that a sense of spirituality or inner God-connection gained in the NDE took precedence, to a large extent, 
over subscribing to formerly held and currently available religious doctrine.

However, it is interesting to note that those who described themselves prior to the NDE as "spiritually oriented, not church involved" or as New Thought Christian or Unity appear to have remained more steadfast in their prior convictions, as these categories did not decrease in number after the NDE but, in fact, significantly increased (spiritual/not church involved, from 29 to 57 percent; New Thought Christian and Unity, from 6 to 16 percent).

Results indicate a decline in percentages in all traditional denominational categories: Protestant (from 45 to 10 percent), Catholic (from 12 to 4 percent), Baptist (from 6 to 2 percent), Jewish (2 percent to none), and Mormons (22 to 16 percent). No changes occurred in the atheist (2 percent) category; but agnostics declined (from 12 to 2 percent). Interestingly, many respondents described being affiliated with more than one religious denomination, particularly before the NDE.

Furthermore, those who considered themselves to be "quite" or "very" personally spiritual and/or religious since their NDE increased (from 43 to 87 percent). Likewise, those with an absolute belief in God increased dramatically (from 24 to 82 percent).

An additional finding of interest was the NDE was associated with a marked increase in belief that there is not just one path to God (28 to 65 percent). This might be related to the finding that only 24 percent reported seeing Jesus during their NDE.

However, of the 12 people who did report having seen Jesus, only 2 (17 percent, or 4 percent of the total surveyed) reported a belief in one path to God. In addition, 6 percent reported a belief after the $\mathrm{NDE}$ in heaven and hell, and 6 percent reported having become "born again" Christians after the NDE.

Results on questions relating to a belief in the afterlife are particularly notable. Definite belief in an afterlife increased dramatically (from 22 to 92 percent). No one after the NDE expressed uncertainty about their response to this question, again suggesting strong, definitive after-NDE attitudes.

Data regarding one's fear of death support the proposed hypothesis: 89 percent reported a decreased or totally eliminated fear of death, while none reported an increased fear.

The respondents in this study reported a marked shift in their conceptions of death after their NDE. These results are particularly interesting since they offer a likely, meaningful explanation for the NDErs' greatly reduced fear of death. 
Belief in heaven and hell fell after the NDE (from 24 to 6 percent), while belief in heaven alone rose (from 8 to 90 percent). In addition, belief in death as a transition increased markedly (from 25 to 92 percent), as did conceptions of death related to reincarnation (from 14 to 37 percent). One might assume that viewing death as a transition and heavenly destination and not a possible hellish state would serve to reduce or eliminate one's fear of death. Further, a belief in reincarnation could also lead to a reduced or absent fear of death, because the death process would have been previously experienced.

Regarding the hypothesis that NDErs' lives are changed for the better, significant majorities of those surveyed reported that since the NDE they were more helpful to others, more appreciative of life, more open-minded and understanding, more religiously open-minded, more intuitive, more aware of spiritual guidance, more purposeful, emotionally stronger, and less fearful in daily living. Reports of strongly positive changes in the areas of spirituality, relationships, lifestyle, and career support these findings and also assist in confirming the initial hypothesis.

These data indicate that some of the most profound changes in after-NDE lives occurred in the areas of personal spirituality and relationships, followed by lifestyle and career. It is interesting that out of the four categories, relationships, while primarily affected positively (78 percent), also had the highest rate of negative effects after an NDE (18 percent), despite data showing that after the NDE, the majority of experiencers gained in qualities that would likely enhance relationships, such as becoming more understanding, more openminded, more intuitive, and more aware of spiritual guidance. This might reflect significant others' difficulty accepting the individuals' NDE and the implications of it, particularly if religious views had been altered. This interpretation is supported by the finding that many of those surveyed were fearful of sharing the NDE with others. One might assume that they were quite selective in doing so.

Additional support for my hypothesis comes from the finding that 77 percent of those surveyed said their lives had changed dramatically as a result of their NDE, 51 percent attributed their having found their life purpose to the NDE, with an additional 22 percent reporting that the NDE somewhat contributed to the discovery of their life purpose. Thus, 73 percent of respondents felt their sense of purpose in life was positively affected by the NDE.

This study, although small in scale, supports and enhances previous research documenting the dramatic, life-changing impact of the 
NDE on an individual. Much of the near-death literature dealt in a general way with the topics addressed by my hypothesis, and much of it focused on the actual NDE and not on the long term after effects of the NDE on the survivor. What research has been done on aftereffects was often presented in an antedotal fashion, without recourse to statistics; and what statistics were available, though interesting, often led to more questions.

The findings of this study are somewhat similar to those reported by Ring and Moody, especially in regard to the actual NDE, the general spiritual impact of the experience, and its after effects. However, the specific questions asked in this survey have not been examined before, such as those pertaining to religion and spirituality, and to encounters with other beings during the NDE.

The survey results proved to be consistent with my proposed hypothesis. Even results suggesting that some NDErs were more depressed ( 8 percent) or had changed for the worse ( 6 percent) were not surprising. NDErs, while admitting positive changes in their lives, often experience varying degrees of confusion and depression also, in a longing for the heavenly experience. Somewhat surprising, however, were findings that many respondents had had more than one NDE, with some persons reporting three or four experiences.

Furthermore, although previous researchers had reported this, I found it curious that only a low percentage of persons encountered Jesus during the NDE, and that while a high percentage of persons reacted favorably to hearing of a NDE, a significant percentage of NDErs were fearful of sharing the NDE with others. One might conclude that those who reacted favorably to others' NDEs had been carefully chosen by the experiencer beforehand, possibly after prior negative experiences in this regard.

\section{Conclusions and Recommendations for Future Research}

Results indicate the majority of NDErs surveyed undergo similar experiences while in the near-death state, which not only alter previously held conceptions, but create similarity in the belief systems of experiencers after the NDE. Such conceptions involve one's personal life and views on religion, God, death, living, and the afterlife.

Major changes occurred in the lives of survey participants as a result of their NDEs in every area proposed by the hypothesis. The 
majority held an absolute belief in God, belief in the afterlife, and considered themselves to be very spiritual after the NDE. In addition, the majority experienced greatly altered conceptions of death, including the loss of a fear of death, and a radical shift in their choice of religious denomination and in their belief regarding a single path to God. Furthermore, a majority attributed their having found their life purpose to the NDE, as well as positive changes in the areas of personal spirituality, relationships, lifestyle, and career.

Further research in specific areas included in this survey could prove to be even more informative, if certain adjustments were made. Using a much larger survey group might provide more conclusive results. In addition, respondents should be instructed to answer questions based on one NDE only, as answers that referred to multiple NDEs proved somewhat confusing to tabulate. The most appropriate denominator for some responses was the number of subjects (51), while that for other responses was the number of NDEs (64).

Questions regarding one's spirituality and religious qualities should not be lumped together but should be separately defined and explored. In addition, the question regarding "one path to God" needs precise definition, as it appeared that some respondents may have assigned different meanings to that phrase.

In the section regarding religious affiliation, respondents should be instructed to choose only one category, so as to avoid possible confusion. Questions addressing changes in one's lifestyle, career, relationships, and spirituality should be more detailed, to examine the nature of the changes. For example, which relationships were affected negatively and which ones positively, and in what ways?

Finally, it would be interesting to add more detailed questions regarding one's experience of Jesus during the NDE, and of any reinforcement of or changes in former religious convictions after the NDE.

\section{References}

Moody, R. A. (1975). Life after life. Covington, GA: Mockingbird Books.

Ring, K. (1984). Heading toward omega: In search of the meaning of the near-death experience. New York, NY: Morrow. 